Masataka Sakai ${ }^{1}$, Shota Noda ${ }^{1}$, Yoshio Kobayashi ${ }^{1 *}$, Ken-ichi Watanabe $^{2}$, Hidekazu Koda ${ }^{2}$, Hiroshi Kunigami ${ }^{2}$, Hideki Kunigami ${ }^{2}$

${ }^{1}$ Ibaraki University, Department of Biomolecular Functional Engineering, College of Engineering, Hitachi, Japan, ${ }^{2}$ K. K. Shinko Kagaku Kogyosho, Koshigaya, Saitama, Japan
Scientific paper

ISSN 0351-9465, E-ISSN 2466-2585

UDC: 620.195

doi: 10.5937/ZasMat1802199S

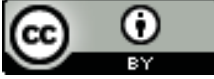

Zastita Materijala 59 (2) 199 - 205 (2018)

\title{
Fabrication of palladium/platinum core-shell nanoparticles by electroless metal plating
}

\begin{abstract}
An electroless metal plating method was used to form metallic platinum (Pt) shells on metallic palladium $(P d)$ nanoparticles. The electroless metal plating method comprised two steps: (1) reduction of $\mathrm{Pd}$ ions to fabricate $\mathrm{Pd}$ nanoparticles and (2) deposition of Pt nuclei and the following formation of Pt shells by immersing the Pd nanoparticles in a Pt-plating solution. TEM observation revealed that the nanoparticles had a size of $5.7 \pm 1.9 \mathrm{~nm}$, were composed of Pd nanoparticles as core and Pt shells. The Pd/Pt core-shell nanoparticles were immobilized electrostatically on carbon support surface-modified with poly(diallyldimethylammonium chloride) (Pd/Pt/C). Cyclic voltammetry revealed that the Pd/Pt/C exerted hydrogen adsorption/desorption, expecting the $\mathrm{Pd} / \mathrm{Pt} / \mathrm{C}$ to function as catalyst for fuel cell.
\end{abstract}

Keywords: palladium, platinum, core-shell, particles, electroless metal plating, catalyst.

\section{INTRODUCTION}

Composites of plural materials are of special interest because they exhibit multiple functions derived from their individual components. Among the numerous structures that have been proposed for functional materials to date, core-shell structures, in which a metallic core particle is coated with a metallic shell, have attracted significant attention owing to their unique properties and potential applications in fields such as catalysis, optics and biotechnology [1-3]. Core-shell structures are also interesting economically because a small amount of expensive material can be used to cover a core of inexpensive material [4].

$\mathrm{Pt}$ is an interesting noble metal because $\mathrm{Pt}$ nanomaterials and nanomaterials containing $\mathrm{Pt}$ exhibit extraordinary chemical and physical properties that can be harnessed for sensors, magnetic materials and catalysts [5-10]. Pt is also used as a catalyst for fuel cells [11-13], and its oxygen reduction reaction (ORR) activity is desired to be improved. According to Zhang et al.'s work, the ORR activity of Pt is dependent on support species,

*Corresponding author: Yoshio Kobayashi e-mail: yoshio.kobayashi.yk@vc.ibaraki.ac.jp Paper received: 24. 01. 2018.

Paper accepted: 26. 02. 2018.

Paper is available on the website: www.idk.org.rs/journal and a metallic palladium support promotes the activity the most efficiently among various metals examined [14]. Their results indicate that composite particles composed of $\mathrm{Pd}$ as core and $\mathrm{Pt}$ as shell will function as the catalyst with high ORR activity. From this viewpoint, several researchers studied on Pd/Pt core-shell nanoparticles for fuel cell catalysts [15-17]. Many studies produced the Pd/Pt core-shell nanoparticles with reduction of $\mathrm{Pt}$ ions to form $\mathrm{Pt}$ with reductant in the presence of $\mathrm{Pd}$ nanoparticles, in which the formation of Pt may take place not only on Pd nanoparticle surface but also in the solution. This may result in production of not only $\mathrm{Pd} / \mathrm{Pt}$ core-shell nanoparticles but also Pt nanoparticles that are not in contact with $\mathrm{Pd}$ nanoparticles. This unexpected production reduces efficiency of fabrication of $\mathrm{Pd} / \mathrm{Pt}$ core-shell nanoparticles.

This study aimed to develop a method for fabricating $\mathrm{Pd} / \mathrm{Pt}$ core-shell nanoparticles. Our previous work performed fabrication of $\mathrm{TiO}_{2} / \mathrm{Pt}$ core-shell particles by electroless metal plating [18]. Because reduction of metal ions to metal takes place at surface of catalyst nuclei deposited on support in the electroless metal plating process, all the generated metal nuclei should be consumed to produce metal layer on the support. The electroless metal plating process was extended to the fabrication of $\mathrm{Pd} / \mathrm{Pt}$ core-shell nanoparticles. The method is composed of two steps. The first step is fabrication of $\mathrm{Pd}$ nanoparticles with reduction of palladium ions in aqueous solution. The $\mathrm{Pd}$ 
nanoparticles were used as catalyst nuclei for the following Pt-plating. The second step is Pt-plating, or formation of $\mathrm{Pt}$ shells on the $\mathrm{Pd}$ nanoparticle surfaces with reduction of platinum ions in the presence of the Pd nanoparticles. The present work also demonstrated immobilization of the $\mathrm{Pd} / \mathrm{Pt}$ nanoparticles on carbon support $(\mathrm{Pd} / \mathrm{Pt} / \mathrm{C})$, and electro-chemical measurement using the $\mathrm{Pd} / \mathrm{Pt} / \mathrm{C}$ to confirm that it has a catalytic activity.

\section{EXPERIMENTAL}

\subsection{Chemicals}

The starting reagents for the $\mathrm{Pd}$ nanoparticles and the Pt shells were $\mathrm{PdCl}_{2}(97.0 \%)$ and hydrogen hexachloroplatinate (IV) hexahydrate $\left(\mathrm{H}_{2} \mathrm{PtCl}_{6} \cdot 6 \mathrm{H}_{2} \mathrm{O}\right)$ (98.5\%), respectively. Ethanol $(99.5 \%)$ was used as both of a solvent and a reducing reagent for $\mathrm{Pd}$ ions in preparation of the $\mathrm{Pd}$ nanoparticle colloid solution. A reducing reagent for $\mathrm{Pt}$ ions was hydrazine monohydrate (98.0\%). Polyvinylpyrrolidone (PVP) (K-30 (Mw=40000)) was used as a dispersing agent in preparation of nanoparticles. Hydrochloric acid $(\mathrm{HCl})(35.0-37.0 \%)$ was used to dissolve the $\mathrm{H}_{2} \mathrm{PtCl}_{6} \cdot 6 \mathrm{H}_{2} \mathrm{O}$ in water. Nafion ${ }^{\mathrm{TM}}$ dispersion solution (5\%, DE520 CS type) and 2-propanol (super special grade) were used for preparing suspension of $\mathrm{Pd} / \mathrm{Pt} / \mathrm{C}$ for fabrication of $\mathrm{Pd} / \mathrm{Pt} / \mathrm{C}$-immobilized electrode. Poly(diallyldimethylammonium chloride) solution (PDADMAC) (20 wt $\%$ in $\left.\mathrm{H}_{2} \mathrm{O}, \quad \mathrm{Mw}=1000,000-2000,000\right)$ was used for surface-modification of the carbon support. An electrolyte for measurement of electro-chemical property was perchloric acid (60.0-62.0\%, Ultrapur). The Nafion ${ }^{\mathrm{TM}}$ dispersion solution and the 2-propanol were purchased from Wako Pure Chemical Industries, Ltd., and the PDADMAC from Sigma-Aldrich Co. LLC. All chemicals besides them were purchased from Kanto Chemicals Co., Inc. The PDADMAC was dialyzed using a cellulose tube (pore size: 5.0 nm, As-One Co., Osaka, Japan) prior to use. All the chemicals besides the PDADMAC were used as received. The water used for solution preparation was ion-exchanged and distilled using an Advantec RFD372VC. The support for the Pd/Pt nanoparticles in the electro-chemical measurement was carbon particles (Carbon Black Vulcan XC-72).

\subsection{Preparation}

To obtain catalyst nuclei in electroless metal plating, Pd nanoparticles were fabricated by the reduction of $\mathrm{Pd}$ ions with the following process. $\mathrm{PdCl}_{2}$ and PVP were added to a co-solvent of 60/40 (v/v) $\mathrm{H}_{2} \mathrm{O}$ /ethanol under sonication, and the mixture was refluxed at $80^{\circ} \mathrm{C}$ for $3 \mathrm{~h}$. The initial concentrations of Pd and PVP were $5.3 \mathrm{mM}$ and 7.6 $\mathrm{g} / \mathrm{L}$, respectively, in the co-solvent.

The formation of $\mathrm{Pd} / \mathrm{Pt}$ core-shell particles was achieved using an electroless metal plating method with the following process. Following previous studies on electroless Pt plating $[18,19]$, a Pt plating solution was prepared by dissolving $\mathrm{H}_{2} \mathrm{PtCl}_{6} \cdot 6 \mathrm{H}_{2} \mathrm{O}$ in a $4 \% \mathrm{HCl}$ aqueous solution to give a $\mathrm{Pt}$ concentration of $19 \mathrm{mM}$. The Pt plating solution and water was added to the $\mathrm{Pd}$ nanoparticle colloid solution at $5^{\circ} \mathrm{C}$. After $1 \mathrm{~h}$, hydrazine was added to the mixture to initiate $\mathrm{Pt}$ deposition $(\mathrm{Pd} / \mathrm{Pt})$. The initial concentrations of $\mathrm{Pd}, \mathrm{PVP}, \mathrm{Pt}$ and hydrazine were $2.9 \mathrm{mM}, 3.8 \mathrm{~g} / \mathrm{L}, 0.80 \mathrm{mM}$ and $20 \mathrm{mM}$, respectively. After $24 \mathrm{~h}$, the solvent of the $\mathrm{Pd} / \mathrm{Pt}$ nanoparticle colloid solution was removed with evaporation under low pressure, and ethanol was added to the residue to re-disperse the nanoparticles in ethanol. The nanoparticles re-dispersed in ethanol were washed with a process composed of centrifugation, removal of the solvent, addition of ethanol, and shaking on a vortex mixer. The washing process was repeated three times.

The $\mathrm{Pd} / \mathrm{Pt}$ nanoparticles were immobilized on the carbon powder for the following electro-chemical measurement with the following process. The Pd/Pt nanoparticles were expected to be colloidally stable in water, because their surface was made ionic due to oxide layer produced with passivation. The carbon surface is hydrophobic. Accordingly, the carbon surface should be hydrophilic to increase affinity between the $\mathrm{Pd} / \mathrm{Pt}$ particle surface and the carbon surface. Thus, prior to the immobilization, the carbon powder was surface-modified with ionic polymer to make the carbon surface hydrophilic with the following process. The carbon particles were added to a PDADMAC aqueous solution under sonication, and the suspension of carbon particles was aged at $35^{\circ} \mathrm{C}$ for $24-48 \mathrm{~h}$ (PDADMAC-C). The initial concentrations of carbon and PDADMAC were 0.27 and $1 \mathrm{~g} / \mathrm{L}$, respectively. After the aging, the PDADMAC-C particles were washed with the same process as for the nanoparticles, in which water, however, was used for the re-dispersion. Subsequently, the colloid solution of washed $\mathrm{Pd} / \mathrm{Pt}$ nanoparticles and water were added to the suspension of washed PDADMAC-C particles, and the mixture was aged at $35^{\circ} \mathrm{C}$ for $6 \mathrm{~h}$ to produce $\mathrm{Pd} / \mathrm{Pt}$-immobilized carbon particles (Pd/Pt/C). The initial concentrations of $\mathrm{Pd}, \mathrm{Pt}$, and carbon were $0.665 \mathrm{mM}, 0.2 \mathrm{mM}$, and $0.135 \mathrm{~g} / \mathrm{L}$, respectively. After the immobilization, the $\mathrm{Pd} / \mathrm{Pt} / \mathrm{C}$ particles were washed with the same process as for the nanoparticles, in which water, however, was used for the re-dispersion. In the final re-dispersion, the concentrations of $\mathrm{Pd}, \mathrm{Pt}$, and carbon were adjusted to $1.33 \mathrm{mM}, 0.4 \mathrm{mM}$, and $0.27 \mathrm{~g} / \mathrm{L}$, respectively, by decreasing the amount of water used for the re-dispersion.

\subsection{Characterization}

Transmission electron microscopy (TEM) was used to investigate the morphology of the nanoparticles and performed with a JEOL JEM-2100 microscope operating at $200 \mathrm{kV}$. To prepare samples for TEM, the colloid solution was dropped on a collodion-coated copper grid, and the 
dispersion medium was evaporated in air, and then in a vacuum. The volume-average particle sizes were determined by measuring dozens of particle diameters in the TEM images. The particle powder was characterized by X-ray diffractometry (XRD). For preparing a powder sample for the XRD measurement, supernatant of the particle colloid was removed by decantation, and then the residue of the colloid was dried at room temperature for $24 \mathrm{~h}$ in a vacuum. The XRD measurements were performed with a Rigaku Ultima IV X-ray diffractometer at $40 \mathrm{kV}$ and $30 \mathrm{~mA}$ using CuKa radiation. The study of the surface composition of particles was performed using $X$-ray photoelectron spectroscopy (XPS) measurements. The XPS samples were produced by the same process as that for the XRD samples. The XPS spectra were obtained using a JEOL JPS-9010 equipped with a monochromatic $\mathrm{Mg}$ Ka radiation source (200 W, 10 $\mathrm{kV}, 1253.6 \mathrm{eV}$ ). To study the composition below the surface, the particles were etched using $500 \mathrm{kV} \mathrm{Ar}^{+}$ sputtering for $1 \mathrm{~min}$. The introduction of PDADMAC on the particle surfaces was qualitatively confirmed using $\zeta$-potential measurements. To measure the $\zeta$-potential of the particles, electrophoretic light scattering (ELS) was performed with a Brookhaven ZetaPlus zeta potential analyzer. Either aqueous $\mathrm{HCl}$ or aqueous $\mathrm{NaOH}$ was added to the colloid solution to vary the $\mathrm{pH}$ for the ELS measurement.

Electro-chemical property of the $\mathrm{Pd} / \mathrm{Pt} / \mathrm{C}$ was measured with a cyclic voltammetry. To fabricate a working electrode, the suspension of $\mathrm{Pd} / \mathrm{Pt} / \mathrm{C}$ nanoparticles, which was prepared by mixing the $\mathrm{Pd} / \mathrm{Pt} / \mathrm{C}$ powder, the $5 \%$ Nafion $^{\mathrm{TM}}$ dispersion solution, and the 2-propanol, was put onto surface of a glassy carbon rotating electrode (Hokuto Denko, HR2-D1-GC5), and then was dried by applying a hot air. A reference electrode and a counter electrode were a reversible hydrogen electrode kit (ALS, 013373) and a platinum electrode (Hokuto Denko, HX-C5), respectively. The CV was performed with a Hokuto Denko HZ-5000 electrochemical measurement system operating at a scan speed of $50 \mathrm{mV} / \mathrm{s}$ in a range of 0.05-1.2 $\mathrm{V}$ in
$0.1 \mathrm{M}$ perchloric acid in nitrogen gas with no rotating.

\section{RESULTS AND DISCUSSION}

\subsection{Pd nanoparticles}

An inset of Fig. 1 (a) shows a photograph of the as-prepared Pd nanoparticle colloid solution. The solution, which was a brownish suspension prior to the reflux, became a black solution during the reflux, implying the reduction of $\mathrm{Pd}^{2+}$ to produce metallic $\mathrm{Pd}$ nanoparticles. No particle sedimentation was observed in the solution, suggesting that the $\mathrm{Pd}$ nanoparticles were colloidally stable. Fig. 1 (a) shows a TEM image of the as-prepared $\mathrm{Pd}$ nanoparticles. The particles were quasi-spherical with an average size of $3.4 \pm 1.3 \mathrm{~nm}$. Fig. 2 (a) shows the XRD pattern of the nanoparticles. Several diffractions were detected at ca. 40, 46 and 68 degrees. It was hard to determine detailed peak angles for the diffractions, since they were not strong. However, these diffractions could be attributed to the (111), (200) and (220) planes of cubic metallic Pd (ICSD No.: 01-071-3757), respectively, which indicated that the production of metallic Pd nanoparticles. This indication supported the implication for production of metallic $\mathrm{Pd}$ nanoparticles.

\subsection{Pd/Pt nanoparticles}

An inset of Fig. 1 (b) shows a photograph of the as-prepared $\mathrm{Pd} / \mathrm{Pt}$ nanoparticle colloid solution prior to the evaporation of solvent. The solution had a color of black. Since Pt nanoparticle colloid solution is blackish as well as Pd nanoparticles, it was hard to confirm production of metallic Pt by naked eyes. The nanoparticles were also colloidally stable because of no observation of particle sedimentation in the solution. Fig. 1 (b) shows a TEM image of the nanoparticles. The particles were quasi-spherical with an average size of $3.6 \pm 1.3 \mathrm{~nm}$. The particle size appeared to slightly increase with the electroless metal plating process, though there was no large increase. The increase in particle size implied formation of Pt shell on Pd nanoparticles.

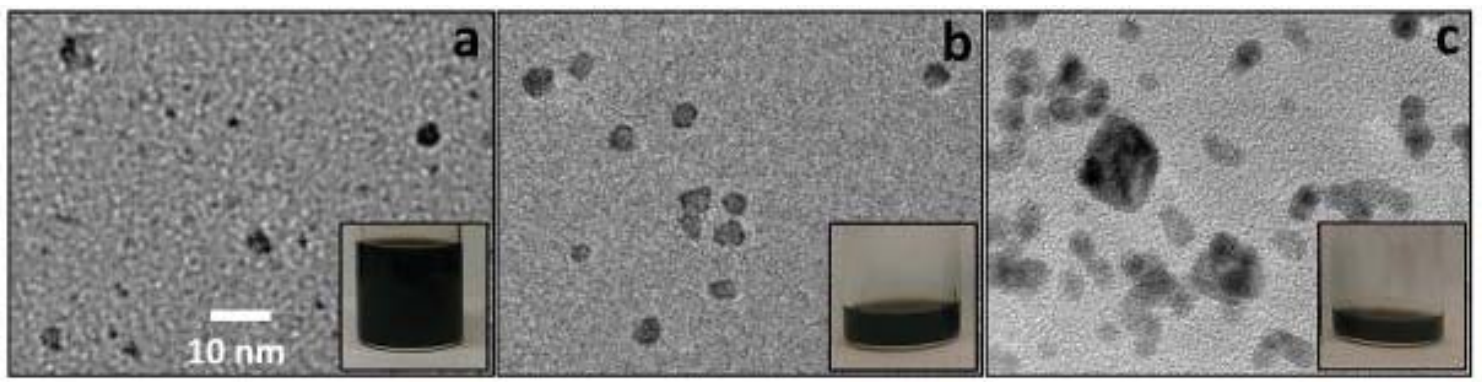

Figure 1. TEM images of (a) Pd nanoparticles, (b) Pd/Pt nanoparticles prior to evaporation of solvent, and (c) $P d / P t$ nanoparticles after the evaporation. Insets show photographs of colloid solutions of them.

Slika 1. TEM slike (a) nanočestica $P d$, (b) nanočestica $P d$ / Pt pre isparavanja rastvarača, $i$ (c) nanočestica $P d$ / Pt nakon isparavanja. Slika pokazuje fotografije njihovih koloidnih rastvora. 
An inset of Fig. 1 (c) shows a photograph of the as-prepared $\mathrm{Pd} / \mathrm{Pt}$ nanoparticle colloid solution after the evaporation of solvent. The solution was still black. The nanoparticles were also colloidally stable because of no observation of particle sedimentation in the solution, so that the evaporation process did not influence the colloidal stability of the particles. Fig. 1 (c) shows a TEM image of the nanoparticles. Nanoparticles appeared to contain a core or multiple cores, and the particles had an average size of $5.7 \pm 1.9 \mathrm{~nm}$. Pt shells became thick with the evaporation of solvent, which increased the particle size. The evaporation of solvent decreased the volume of solution, which increased various concentrations of species such as Pd particles, generated Pt nuclei and unreacted chemicals.

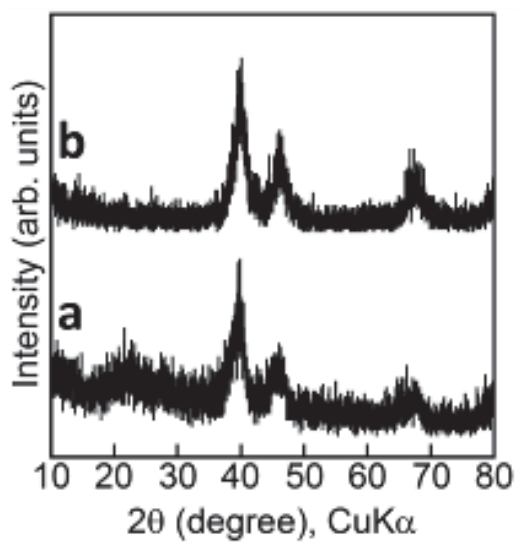

Figure 2. XRD patterns of (a) Pd nanoparticles and

(b) Pd/Pt nanoparticles after the evaporation.

Slika 2. XRD spektri (a) nanočestica Pd i (b) nanočestica Pd / Pt nakon isparavanja.

The increase in the concentrations of unreacted chemicals increased ionic strength of the solution. Increased ionic strength has been reported to compress the double layer of colloidal particles
[20-22]. The evaporation of solvent therefore decreased the double-layer repulsion between the Pd nanoparticles and the Pt nuclei. The increased ionic strength was thus primarily responsible for the adsorption of the Pt nuclei on the Pd nanoparticles in the present system. The adsorption was then followed by formation of the Pt shells, or formation of core-shell structure. It should be noted that several nanoparticles appeared to contain multiple cores. The evaporation of solvent also decreased the double-layer repulsion between the $\mathrm{Pd}$ nanoparticles. The increased ionic strength was also responsible for the aggregation of $\mathrm{Pd}$ nanoparticles in the present system. The aggregates were then coated with Pt shells, which resulted in the production of nanoparticles containing the multiple Pd nanoparticles as the core. Fig. 2 (b) shows the XRD pattern of the nanoparticles. Several diffractions were detected at ca. 40, 46 and 68 degrees as well as the Pd nanoparticles. There were two possibilities in attribution of these diffractions. One was the (111), (200) and (220) planes of cubic metallic Pd, and the other was the (111), (200) and (220) planes of cubic metallic Pt (ICSD No.: 01-071-3756). It was hard to conclude which attribution was reasonable, because there is no large difference in $d$-spacing between cubic metallic Pd ( $d$-spacing: $0.389 \mathrm{~nm}$ ) and cubic metallic Pt ( $d$-spacing: $0.392 \mathrm{~nm})$, and the diffractions for the Pd/Pt nanoparticles were also not strong. According to our previous work on $\mathrm{TiO}_{2} / \mathrm{Pt}$ core-shell particles fabricated with the electroless metal plating method, the crystalline Pt shells formed on the $\mathrm{TiO}_{2}$ particles [18]. Since the electroless metal plating process in the present system was quite similar to that in our previous work, the crystalline Pt shells were considered to be also obtained in the present system, though the XRD did not remarkably provide conclusion on formation of crystalline Pt shells.

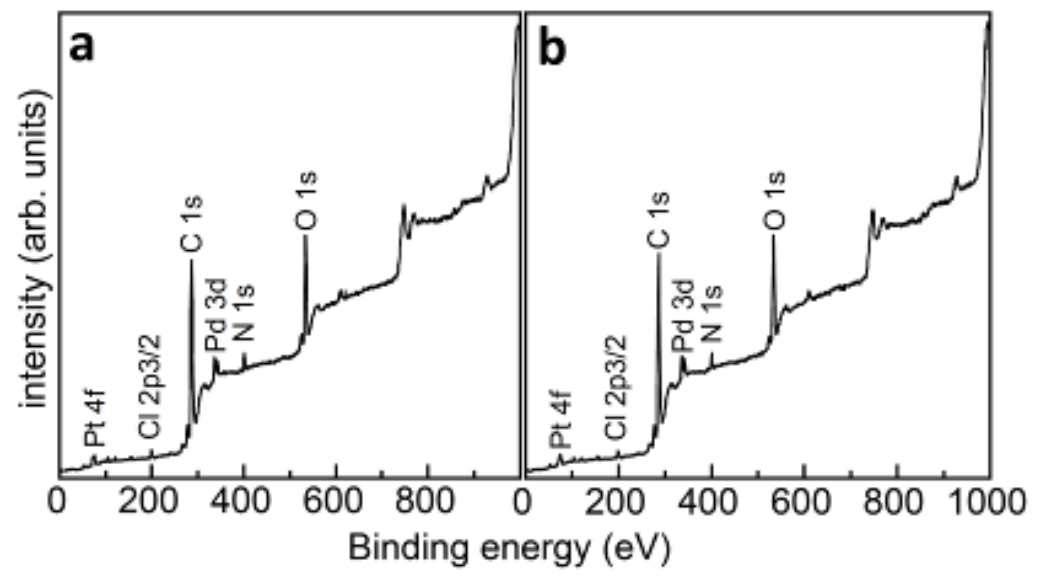

Figure 3. XPS spectra of Pd/Pt nanoparticles (a) prior to and (b) after Ar+ etching

Slika 3. XPS spektri nanočestica Pd / Pt (a) pre i (b) nakon Ar+ nagrizanja 
Fig. 3 shows the XPS patterns of the nanoparticles. The XPS measurement revealed existence of elements of $\mathrm{Pd}$ and $\mathrm{Pt}$. Atomic ratios of $\mathrm{Pd}+\mathrm{Pt}$ for the surfaces of the Pd/Pt nanoparticles were estimated from the XPS peak area intensity. Prior to the $\mathrm{Ar}^{+}$etching, the atomic ratios of $\mathrm{Pd}$ and Pt were 73.2 and 26.8 atom\%, respectively. These ratios increased to 74.3 atom\% and decreased to 25.7 atom\%, respectively, after the $\mathrm{Ar}^{+}$etching. This result indicated that the etching of the particle surface revealed the surface of the $\mathrm{Pd}$ particles, which further supported the formation of Pt shells on the Pd nanoparticles.

\subsection{Surface-modified carbon particles}

Figs. 4 (a) and (b) show TEM images of the as-received and the surface-modified carbon particles, respectively. The as-received carbon particles were spherical particles with a size of $44.9 \pm 13.9 \mathrm{~nm}$. The surface-modified carbon particles were also spherical particles, and had a size of $41.6 \pm 11.0 \mathrm{~nm}$ that was almost the same as that of the as-received carbon particles. Accordingly, it was hard to confirm existence of PDADMAC on the carbon particles. Fig. 5 shows the $\zeta$-potentials of various carbon powders as a function of the $\mathrm{pH}$. In the as-received carbon and the surface-modified carbon fabricated for a surface-modification time of $24 \mathrm{~h}$, the $\zeta$-potentials decreased and passed through isoelectric points (IEP) as the $\mathrm{pH}$ increased. The IEPs of the as-received carbon and the surface-modified carbon were 4.0 and 9.0, respectively. The IEP for the surface-modified carbon was higher than that for the as-received carbon. Because the PDADMAC is a cationic polymer, this shift to higher $\mathrm{pH}$ indicated that the PDADMAC molecules were present on the carbon powder surface, or the carbon powder surface was successfully modified with the PDADMAC. The surface-modified carbon fabricated for a surface-modification time of $48 \mathrm{~h}$ did not have an IEP, and had positive $\zeta$-potentials in the range of $\mathrm{pH}$ examined. This indicated that an increase in surface-modification time increased the amount of PDADMAC on particles. As a result, the carbon surface became cationic.

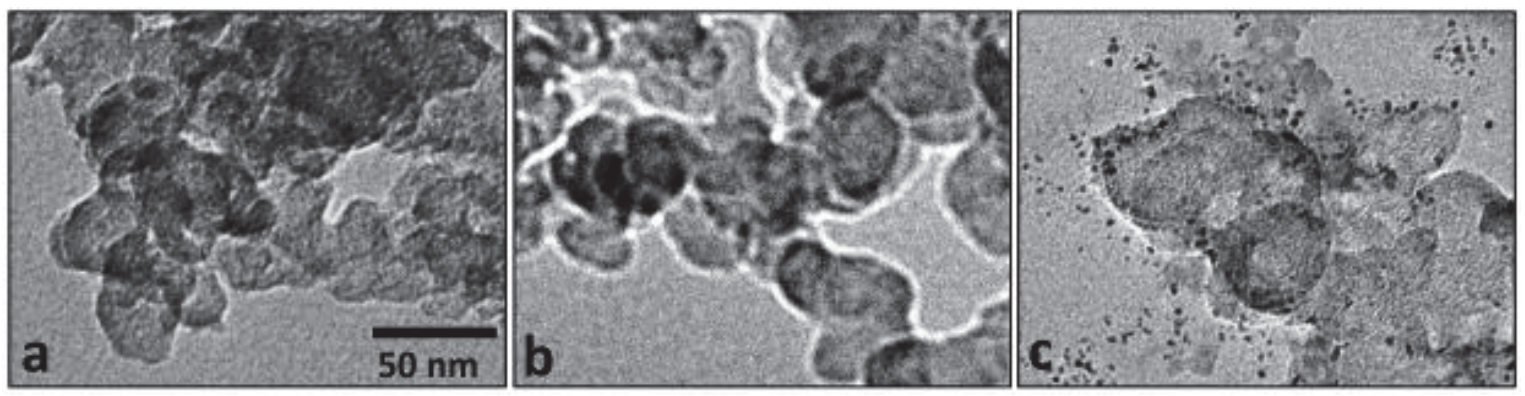

Figure 4. TEM images of (a) as-received carbon particles, (b) surface-modified carbon particles fabricated with a surface-modification time of $24 \mathrm{~h}$, and (c) Pd/Pt/C particles produced using surface-modified carbon particles fabricated with a surface-modification time of $48 \mathrm{~h}$

Slika 4. TEM slike (a) ugljeničnih čestica kako su primljene, (b) površinski modifikovane čestice ugljenika izrađene sa vremenskim modifikacijom od 24 h, i (c) čestice Pd / Pt / C proizvedene korišćenjem površinski modifikovanih ugljeničnih čestica proizvedenih sa površina sa vremenskom modifikacijom od $48 \mathrm{~h}$

\subsection{Pd/Pt/C powder}

Fig. 4 (c) shows a TEM image of $\mathrm{Pd} / \mathrm{Pt} / \mathrm{C}$ powder. Darker and lighter parts of particles were determined to be $\mathrm{Pd} / \mathrm{Pt}$ particles and carbon powder, respectively, due to the electron density differences between them. The Pd/Pt nanoparticles were immobilized on the carbon, though several $\mathrm{Pd} / \mathrm{Pt}$ nanoparticles were not. The ELS measurement revealed that the surface-modified carbon was cationic in the range of $\mathrm{pH}$ ca. 3-12, as shown in Fig. 5 (c). According to studies on zeta-potentials of $\mathrm{Pt}$ nanoparticles $[23,24]$, the $\mathrm{Pt}$ nanoparticles have an isoelectric point of ca. 3; The $\mathrm{Pt}$ nanoparticle surface should be anionic at neutral $\mathrm{pH}$. Since the Pd/Pt-immobilization was performed at neutral $\mathrm{pH}$, the $\mathrm{Pt}$ surface of $\mathrm{Pd} / \mathrm{Pt}$ nanoparticles and the surface of surface-modified carbon powder were probably anionic and cationic, respectively. This indicated that electrostatic attractive power acted on them. Consequently, the $\mathrm{Pd} / \mathrm{Pt}$ nanoparticles were immobilized on the surface-modified carbon powder.

Fig. 6 shows a cyclic voltammetry curve for $\mathrm{Pd} / \mathrm{Pt} / \mathrm{C}$. A negative peak detected at ca. $0.7 \mathrm{~V}$ was ascribed to reduction of $\mathrm{Pt}$ oxide. Peaks based on hydrogen adsorption/desorption were detected in a voltage range as low as ca. 0-0.3 V. The result on the detection expected the $\mathrm{Pd} / \mathrm{Pt} / \mathrm{C}$ to function as a catalyst for fuel cell. A charge required to oxidize a monolayer of hydrogen adsorbed on $\mathrm{Pt}$ is 210 $\mu \mathrm{C} / \mathrm{cm}^{2}$, and an integrated charge amount for hydrogen adsorption in a range of 0.05-0.4 $\mathrm{V}$ was 47.5 $\mu \mathrm{C}$ in Fig. 5, which corresponded to a total electrochemical active area of $0.226 \mathrm{~cm}^{2}$. An electrochemical active area for Pt loading in catalyst $(E A A)\left(\mathrm{cm}^{2} / \mathrm{g}-\mathrm{Pt}\right)$ is required to evaluate a Pt catalyst precisely. Accordingly, further electrochemical characterizations are required to be performed in a 
future work for evaluating catalytic properties of the $\mathrm{Pd} / \mathrm{Pt} / \mathrm{C}$.

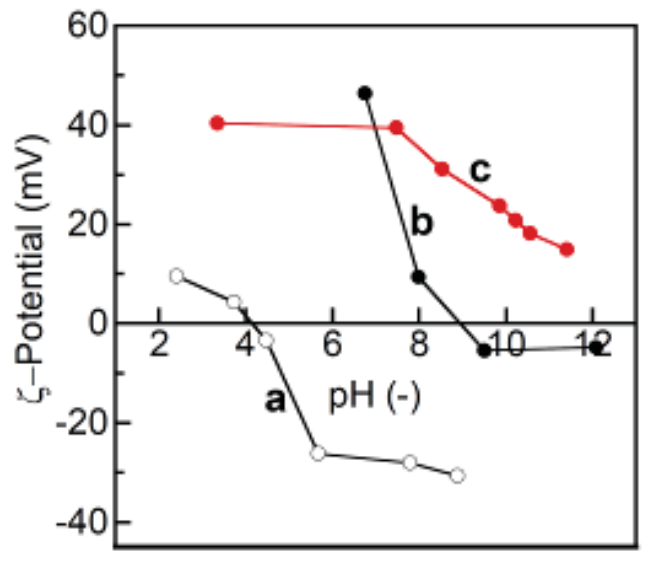

Figure 5. $\zeta$-Potentials of (a) as-received carbon particles, (b) surface-modified carbon particles fabricated with a surface-modification time of $24 \mathrm{~h}$, and (c) surface-modified carbon particles fabricated with a surface-modification time of $48 \mathrm{~h}$

Slika 5. ל-Potencijali od (a) ugljeničnih čestica kako su primljeni, (b) površinski modifikovane čestice ugljenika izrađene sa vremenskom modifikacijskom od 24 h, i (c) površinski modifikovane čestice ugljenika proizvedene sa vremenom modifikacije od $48 \mathrm{~h}$

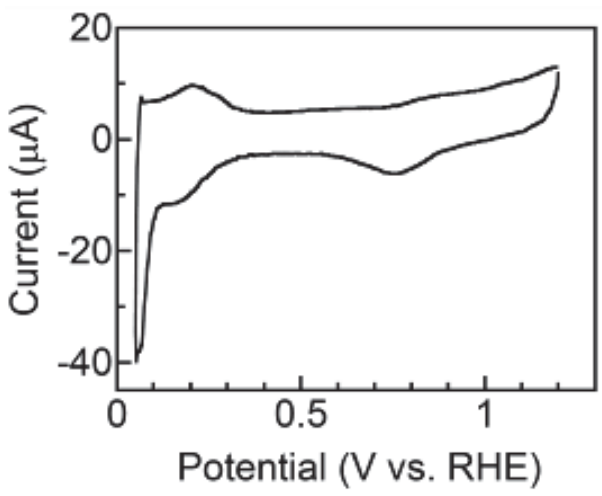

Figure 6. Cyclic voltammogram of Pd/Pt/C particles. The Pd/Pt/C particles used for the measurement was the sample (c) in Fig. 4

Slika 6. Ciklični voltamogram čestica Pd / Pt / C. Čestice Pd / Pt / C koje su korišćene za merenje bile su uzorak (c) na slici 4

\section{CONCLUSIONS}

The Pd nanoparticles with the size of $3.4 \pm 1.3$ $\mathrm{nm}$ were produced by the reduction of $\mathrm{Pd}$ ions, and then the Pt shells were fabricated on the surfaces of the Pd nanoparticles by using the electroless metal plating technique. The size of $\mathrm{Pd} / \mathrm{Pt}$ core-shell nanoparticles after the evaporation treatment was
$5.7 \pm 1.9 \mathrm{~nm}$. The surfaces of carbon support powder were modified with the PDADMAC with the cationic group, and then the Pd/Pt core-shell nanoparticles with anionic surfaces were immobilized electrostatically on the surface-modified carbon support. The hydrogen adsorption/desorption took place for the $\mathrm{Pd} / \mathrm{Pt} / \mathrm{C}$ powder. A study on application of the $\mathrm{Pd} / \mathrm{Pt} / \mathrm{C}$ particles to catalyst for fuel cells is being prepared for their practical use.

\section{Acknowledgements}

This work was partially supported by K. K. Shinko Kagaku Kogyosho. We express our thanks to Prof. T. Noguchi at the College of Science of Ibaraki University, Japan (current affiliation: Faculty of Arts and Science of Kyushu University, Japan) for his help with the TEM observation.

\section{REFERENCES}

[1] S. Saha, A. Basu, D. Das, A. Ganguly, D. Banerjee, K. Kargupta (2016) Novel graphene supported Co rich connected core (Pt)-shell (Co) nano-alloy catalyst for improved hydrogen generation and electro-oxidation, International Journal of Hydrogen Energy, 41, 18451-18464.

[2] Y. Liu, J. Dai, L. Xu, X. Liu, J. Liu, G. Li (2016) Red to brown to green colorimetric detection of $\mathrm{Ag}^{+}$based on the formation of Au-Ag core-shell NPs stabilized by a multi-sulfhydryl functionalized hyperbranched polymer, Sensors and Actuators B, 237, 216-223.

[3] L. Song, K. Mao, X. Zhou, J. Hu (2016) A novel biosensor based on Au@Ag core-shell nanoparticles for SERS detection of arsenic (III), Talanta, 146, 285-290.

[4] B. J. Jankiewicz, D. J. Jamiola, C. M. Jaroniec (2012) Silica-metal core-shell nanostructures, Advances in Colloid and Interface Science, 170, 28-47.

[5] S. W. Choi, J. Kim, Y. T. Byun (2017) Highly sensitive and selective $\mathrm{NO}_{2}$ detection by $\mathrm{Pt}$ nanoparticles-decorated single-walled carbon nanotubes and the underlying sensing mechanism, Sensors and Actuators B, 238, 1032-1042.

[6] C. Yu, Y. Wu, X. Liu, F. Fu, Y. Gong, Y. J. Rao, Y. Chen (2017) Miniature fiber-optic $\mathrm{NH}_{3}$ gas sensor based on $\mathrm{Pt}$ nanoparticle-incorporated graphene oxide, Sensors and Actuators B, 244, 107-113.

[7] S. B. Dalavi, R. N. Panda (2017) Observation of high coercive fields in chemically synthesized coated Fe-Pt nanostructures, Journal of Magnetism and Magnetic Materials, 428, 306-312.

[8] H. Shokrollahi, A. Khorramdin, G. Isapour (2014) Magnetic resonance imaging by using nano-magnetic particles, Journal of Magnetism and Magnetic Materials, 369, 176-183.

[9] Y. Li, Y. Fan, J. Jian, L. Yu, G. Cheng, J. Zhou, M. Sun (2017) Pt-based structured catalysts on metallic supports synthesized by electroless plating deposition for toluene complete oxidation, Catalysis Today, 281, 542-548.

[10] K. Sondomoyee, S. M. A. Moromi, H. Siddiki, K. Kon, T. Toyao, K. Shimizu (2017) Acceptorless dehydrogenation of $\mathrm{N}$-heterocycles by supported $\mathrm{Pt}$ catalysts, Catalysis Today, 281, 507-511. 
[11] R. M. Antoniassi, L. Otubo, J. M. Vaz, A. O. Neto, E. V. Spinacé (2016) Synthesis of Pt nanoparticles with preferential (100) orientation directly on the carbon support for direct ethanol fuel cell, Journal of Catalysis, 342, 67-74.

[12] J. Zhang, X. Yi, S. Liu, H. L. Fan, W. Ju, Q. C. Wang, J. Ma (2017) Vertically aligned carbon nanotubes/carbon fiber paper composite to support Pt nanoparticles for direct methanol fuel cell application, Journal of Physics and Chemistry of Solids, 102, 99-104.

[13] S. Hussain, H. Erikson, N. Kongi, M. Merisalu, P. Ritslaid, V. Sammelselg, K. Tammeveski, Heat-treatment effects on the ORR activity of $\mathrm{Pt}$ nanoparticles deposited on multi-walled carbon nanotubes using magnetron sputtering technique, International Journal of Hydrogen Energy, 9, 5958-5970.

[14] J. Zhang, M. B. Vukmirovic, Y. Xu, M. Mavrikakis, R. R. Adzic (2015) Controlling the catalytic activity of platinum-monolayer electrocatalysts for oxygen reduction with different substrates, Angewandte Chemie International Edition, 44, 2132-2135.

[15] N. M. Sánchez-Padilla, D. Morales-Acosta, M. D. Morales-Acosta, S. M. Montemayor, F. J. Rodríguez-Varela (2014) Catalytic activity and selectivity for the ORR of rapidly synthesized M@Pt $\left(\mathrm{M}=\mathrm{Pd}, \mathrm{Fe}_{3} \mathrm{O}_{4}, \mathrm{Ru}\right)$ core-shell nanostructures, International Journal of Hydrogen Energy, 39, 16706-16714.

[16] Y. W. Lee, J. Y. Lee, D. H. Kwak, E. T. Hwang, J. I. Sohn, K. W. Park (2015) Pd@Pt core-shell nanostructures for improved electrocatalytic activity in methanol oxidation reaction, Applied Catalysis B, 179, 178-184.

[17] J. Park, M. Vara, Y. Xia (2017) A systematic study of the catalytic durability of Pd@Pt2-3L nano-sized octahedra toward oxygen reduction, Catalysis Today, 280, 266-273.

[18] Y. Kobayashi, Y. Ishii, H. Yamane, K. Watanabe, H. Koda, H. Kunigami, H. Kunigami (2014) Fabrication of $\mathrm{TiO}_{2} / \mathrm{Pt}$ core-shell particles by electroless metal plating, Colloids and Surfaces A, 448, 88-92.

[19] C. M. Chen, C. H. Chen, S. J. Cherng, T. C. Wei (2010) Electroless deposition of platinum on indium tin oxide glass as the counter electrode for dye-sensitized solar cells, Materials Chemistry and Physics, 124, 173-178.

[20] D. Dickson, G. Liu, C. Li, G. Tachiev, Y. Cai (2012) Dispersion and stability of bare hematite nanoparticles: effect of dispersion tools nanoparticle concentration humic acid and ionic strength, Science of the Total Environment, 419, 170-177.

[21] Z. Li, J. Li, R. Xu, Z. Hong, Z. Liu (2015) Streaming potential method for characterizing the overlapping of diffuse layers of the electrical double layers between oppositely charged particles, Colloids and Surfaces A, 478, 22-29.

[22] K. Dimic-Misic, M. Hummel, J. Paltakari, H. Sixta, T. Maloney, P. Gane (2015) From colloidal spheres to nanofibrils: extensional flow properties of mineral pigment and mixtures with micro and nanofibrils under progressive double layer suppression, Journal of Colloid and Interface Science, 446, 31-43.

[23] E. McCafferty (2010) Relationship between the isoelectric point $\left(\mathrm{pH}_{\mathrm{pzc}}\right)$ and the potential of zero charge $\left(E_{p z c}\right)$ for passive metals, Electrochimica Acta, 55, 1630-1637.

[24] G. Marzun, C. Streich, S. Jendrzej, S. Barcikowski, P. Wagener (2014) Adsorption of colloidal platinum nanoparticles to supports: charge transfer and effects of electrostatic and steric interactions, Langmuir, 30, 11928-11936.

\section{IZVOD}

\section{IZRADA PALADIJUM / PLATINSKOG JEZGRA NANOČESTICA ELEKTROSTATSKIM METALNIM PREMAZOM}

Metoda pločica bez elektrolita je korišćena da se formiraju metalne čestice školjke platine (Pt) na nanočesticama metalnog paladijuma $(P d)$. Metoda neplastičnog metala je obuhvatila dva koraka: (1) smanjenje jona $P d$ za proizvodnju Pd nanočestica $i$ (2) deponovanje jezgra Pt $i$ sledeće formiranje Pt školjki potapanjem Pd nanočestica u Pt- rastvor. TEM posmatranje je otkrilo da nanočestice imaju veličinu od $5,7 \pm 1,9 \mathrm{~nm}$, sastoje se od nanočestica Pd kao jezgra i Pt školjki. Nanočestice Pd / Pt jezgra su bili elektrostatički imobilizovani na površini ugljenika, modifikovanim sa poli (diallildimethilammonium chloride) $(P d / P t / C)$. Ciklična voltametrija pokazala je da je $P d / P t$ / C imala adsorpciju vodonika / desorpciju, očekujući da Pd / Pt / C funkcioniše kao katalizator za gorivne ćelije.

Ključne reči: paladijum, platina, jezgro -čestice, elektrostatska metalna galvanizacija, katalizator.

Naučni rad

Rad primljen: 24.01. 2018.

Rad prihvaćen: 26. 02. 2018.

Rad je dostupan na sajtu: www.idk.org.rs/casopis

(c) 2018 Authors. Published by Engineering Society for Corrosion. This article is an open access article distributed under the terms and conditions of the Creative Commons Attribution 4.0 International license (https://creativecommons.org/licenses/by/4.0/) 